\title{
Daphnia lumholtzi Sars, 1885 (Cladocera: Daphniidae) invades Argentina
}

\author{
Alexey A. KOTOV, ${ }^{1 *}$ Derek J. TAYLOR ${ }^{2}$ \\ ${ }^{1}$ A.N. Severtsov Institute of Ecology and Evolution, Leninsky Prospect 33, Moscow 119071, Russia; ${ }^{2}$ Department of Biological Sciences, \\ The State University of New York at Buffalo, NY 14260, USA \\ *Corresponding author: alexey-a-kotov@yandex.ru
}

\begin{abstract}
The extent of freshwater biological invasions is difficult to predict. The thermophilic Daphnia lumholtzi Sars, 1885 (Cladocera: Daphniidae) has successfully invaded a large section of temperate North America from an Old World source, damaging ecosystems and fisheries. The species was later reported introduced into Mexico and Brazil. Here we report D. lumholtzi in Argentina - the most southerly record in the New World for this species. Our genetic analyses establish haplotype identity with North American specimens, consistent with the colonization of South America from North America. The detection dates of the records in South America and the association with the Paraná River, provide evidence that river ways play a role in expansion of $\mathrm{D}$. lumholtzi. The invasion of $\mathrm{D}$. lumholtzi has now reached a similar wide latitudinal span to the distribution in the Old World.
\end{abstract}

Key words: Daphnia, invasion, Cladocera, zooplankton, neotropical.

Received: December 2013. Accepted: January 2014.

\section{INTRODUCTION}

Intercontinental invasions are among the most important threats to fragile freshwater ecosystems. However, predicting the geographic extent and success of these invasions has proved difficult (Moyle and Marchetti, 2006; Hayes and Barry 2008). Often the predictive traits are limited to a species, a particular habitat-species combination or a particular stage of invasion. The lack of generalities and predictability for biological introductions has been given pessimistic names such as the Frankenstein effect (Moyle, 1986) and the key-lock effect (Heger and Trepl, 2003).

Cladocerans are one freshwater group that might be expected to have numerous widespread invaders because of their mixed sexual/asexual breeding system - one propagule can lead to successful colonization. However, there is wide variation in the success of cladoceran invaders. Daphnia obtusa Kurz, 1874, for example, is known to invade one location in Australia (Benzie and Hodges, 1996). The strictly asexual panarctic D. pulex, however, has expanded recently to nearly every continent from its source in North America (Mergeay et al., 2005; Crease et al., 2012; Burns 2013). Other invaders have taken several decades to expand across one continent such as Bosmina (Eubosmina) coregoni Baird, 1857 in North America (Lieder, 1991; Haney and Taylor, 2003). The success of other cladoceran invasions can be difficult to quantify because of hybridization, morphologically challenging taxa, and introductions that occurred before taxonomic discovery.

One of the most morphologically conspicuous invaders among daphniids is Daphnia lumholtzi Sars, 1885 in North America. The species is thermophilic, initially distributed predominantly in tropics-subtropics of Old World (Fig. 1A). Large defensive spines and pronounced success in reservoirs in North America have meant that this species has a negative effect on native ecosystems and fisheries (Swaffar and O’Brien, 1996; Havens et al., 2000). D. lumholtzi was first established in North America in 1983 in association with mass stocking of African Blue Tilapia Oreochromis aureus (Steindachner, 1864) or/and Nile perch Lates niloticus (Linnaeus, 1758) to Fairfield Reservoir, Texas (Sorensen and Sterner, 1992; Havel and Hebert, 1993). Then, D. lumholtzi rapidly colonized 20 other states, reaching $46-47^{\circ} \mathrm{N}$ (NW corner of Lake Superior, also present in vicinities of Lake Michigan and Lake Erie), and $27^{\circ} \mathrm{N}$ moving South (Florida) (Benson et al., 2014). During last decade it was detected in NE Mexico, reaching initially $28-29^{\circ} \mathrm{N}$ (Elías-Gutiérrez et al., 2008) and then $24^{\circ} \mathrm{N}$ (Silva-Briano et al., 2010). Dispersal is thought to occur by river systems and by boat traffic. In 2000, D. lumholtzi was found in São Paulo State of Brazil, reaching $21^{\circ} \mathrm{S}$ (Zanata et al., 2003), and then it occupied several water bodies in the upper Paraná River basin in Brazil (Simões et al., 2009), at 22-23ㅇ S (Fig. 1B). However, it is still unknown if these introductions are an expansion of the North American invasion or a separate introduction from the Old World tropics. Analysing samples from a survey collected in Argentina in 2006, we found that $D$. lumholtzi occurred much further south in the New World because we found it in Santa Fe Province, at almost $32^{\circ} \mathrm{S}$. Our genetic analyses are consistent with expansion of $D$. lumholtzi into southern South America from North America. 


\section{METHODS}

Collections were made in Argentina and Chile in 2006. D. lumholtzi was collected in a pool (coordinates: $31.6631^{\circ} \mathrm{S} ; 60.5935^{\circ} \mathrm{W}$ ) adjacent to the Paraná River, between Paraná and Santa Fe, Santa Fe Province on 19 February 2006 by A. Anderson, L. Hovind, W.H. Piel (Fig. 1). Samples were taken by a plankton net and immediately fixed in $96 \%$ alcohol. In the laboratory, the samples were sorted under a binocular stereoscopic microscope. Specimens were placed on slides (in a drop of a glycerol-formaldehyde mixture) and studied under an optical microscope in toto. Photomicrographs were taken with an Infinity camera attached to the Olympus CX-41 Microscope. DNA extraction from individual ethanol-preserved animals was achieved using the DNA Quickextract extraction kit from Epicentre. Fifty microlitres of PCRs contained $5 \mu \mathrm{L}$ of extracted DNA template, 10x PCR buffer [50 mM KCl, $1.5 \mathrm{mg} \mathrm{MgCl} 2,10$ $\mathrm{mM}$ Tris- $\mathrm{HCl}, \mathrm{pH} 8.3,0.01 \%$ (w/v) gelatin], $2 \mathrm{mM}$ of each dNTP, $1 \mathrm{mM}$ of each primer and $1 \mathrm{U}$ of Taq DNA polymerase. We used primers from Folmer et al. (Folmer et al., 1994) for the mitochondrial COI fragment. The PCR temperature profiles were: 40 cycles of $94^{\circ} \mathrm{C}$ for $30 \mathrm{~s}, 48^{\circ} \mathrm{C}$ for $30 \mathrm{~s}$ and $72^{\circ} \mathrm{C}$ for $2 \mathrm{~min}$, and final exten- sion at $72^{\circ} \mathrm{C}$ for $5 \mathrm{~min}$. DNA was sequenced by Sanger methods at the University of Washington High Throughput Genomics Facility. Geneious 7.0.4 (Biomatters Development Team) was used to assemble, edit and verify open-reading frames. We used MAFFT to align the sequences, jmodeltest 2 Darriba et al., 2012 to assess sequence models, and PhyML (as implemented in Seaview) to estimate best trees under the ML criterion. We used the best tree of NNI (nearest neighbor interchange) and SPR (subtree pruning and redrafting) searches combined. Branch support values were estimated from approximate likelihood ratios (aLRTs). The optimal substitution model as estimated by jModeltest 2 was the HKY 85 (Hasegawa et al., 1985)+gamma.

In addition to our sequences from the specimens collected in Argentina and taken from the Genbank, we obtained new sequences from specimens isolated from the USA and from Thailand (Tab. 1).

\section{RESULTS}

The unmistakable morphology of the anterior projection on head, fornices, spinulation on postero-ventral margin of valve etc. in our study reveal that just $D$. lumholtzi has been found (Fig. 2 A-D).

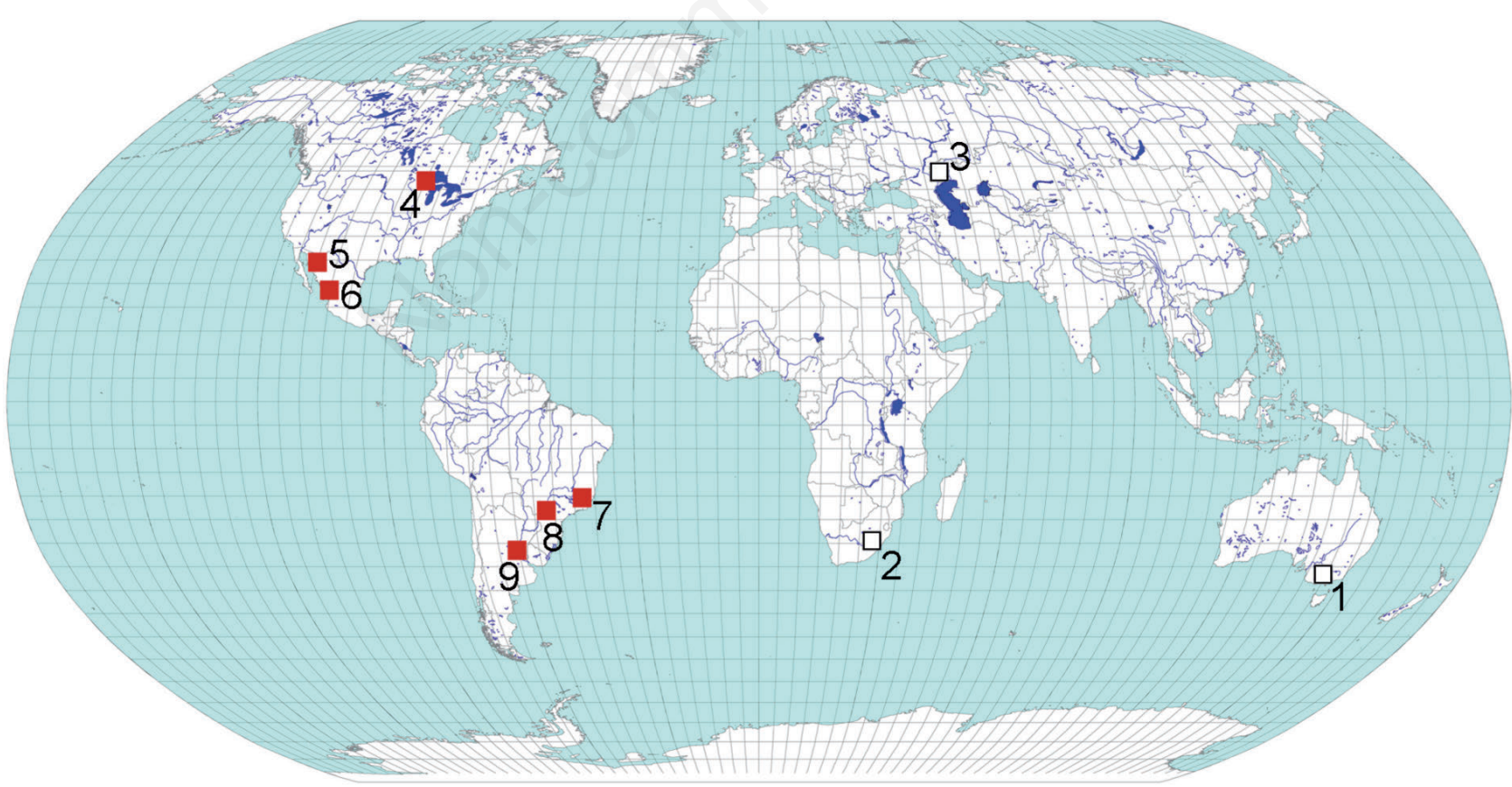

Fig. 1. Some native (empty squares) and invasive (solid squares, red in the electronic version) distributional records of Daphnia lumholtzi. Legend to numbers: 1, southernmost point in Australia (Benzie, 2005); 2, southernmost point in Africa (Smirnov, 2008); 3, nothernmost point in Eurasia (Behning, 1928; Glagolev, 1995); 4, northernmost point in North America (Benson et al., 2013); 5, first record in Mexico (Elías-Gutiérrez et al., 2008); 6, southernmost point in Mexico (Silva-Briano et al., 2010); 7, first record in South America (Zanata et al., 2003); 8, next record in Brazil (Simões et al., 2009); 9, this study. 
A maximum likelihood tree based on mitochondrial sequence is represented in Fig. 2E. Australian and AsianAfrican clades of $D$. lumholtzi are deeply divergent and represent at least two independent species. All North American and newly created South American populations definitively belong just to the Asian-African clade [most probably, to an African sub-clade (Havel et al., 2000)]. Among three haplotypes found in Argentina, two are exactly identical to those from USA, and the third one also grouped within the North American clade.

\section{DISCUSSION}

The sequence identity of South American specimens with North American specimens is consistent with shared recent ancestry. Australian and Africa-Asian clades form at least two divergent lineages. Their possible differences in biology are unknown. Morphologically cryptic species have been proposed for $D$. lumholtzi in prior studies (Behning, 1928; Kořínek, 2002).

Since $D$. lumholtzi is known to disperse by river systems, the simplest hypothesis for the immediate source of the Argentinian D. lumholtzi is dispersal from the Brazilian populations of the Upper Paraná River detected in 2003 (Simões et al., 2009). We found $D$. lumholtzi in the Lower Paraná three years later in 2006. Many water bodies near this large river are frequently flooded and connected with the main river stream during the wet season. Ephippia and parthenogenetic females can disperse by the river current. We suspect that the whole basin of the Paraná River is invaded by $D$. lumholtzi now. Absence of records in the areas between points, where it is found to date, might be explained by insufficient sampling effort, especially in the shallow oxbows near the rivers. D. lumholtzi has reached 31$32^{\circ} \mathrm{S}$ in South America. Therefore its invasive distribu- tional area is significantly increased since the first record on the South American continent (Zanata et al., 2003). High-resolution genetic markers might provide further testing of the origination of the Argentinian populations from Brazilian populations (Frisch et al., 2013). Also mysterious is the method of dispersal from North America to South America. Tropical lowlands (including South America) are relatively poor of Daphnia species (Dumont, 1980; Fernando et al., 1987; Paggi, 1993; Popova and Kotov, 2013). Dzialowski et al. (2000) hypothesized that by occupying a niche that was previously unexploited by Daphnia, D. lumholtzi competed with non-daphnid zooplankton otherwise able to obtain resources during that time. Water bodies lacking aboriginal Daphnia species are even more common in tropical-subtropical areas of South America. At the same time, members of the $D$. laevis species group inhabit many tropical-subtropical water bodies of Argentina (Adamowicz et al., 2004). Although lacking projecting fornices, these native daphniids are about the same size as the exotic species, have long caudal needle and high and/or pointed helmet (Herbst, 1967; Paggi, 1977), that protects them against predators in the same way as in $D$. lumholtzi.

Often the original distribution of $D$. lumholtzi is portrayed as tropical or subtropical (Benzie, 2005; Wittmann et al., 2013). However, in the Old World, D. lumholtzi s. lat. is distributed North until about $46-47^{\circ} \mathrm{N}$ (the Volga and Ural deltas, Caspian Region of Russia, see Behning, 1928; Glagolev, 1995). At the same time, in its non-indigenous range in the New World, D. lumholtzi, reached almost the same latitudes (about $45^{\circ} \mathrm{N}$ ) as in the Old World. In both South Africa and Australia D. lumholtzi is distributed up to (or almost up to) the southernmost extremities of these continents. It was reported from about

Tab. 1. COI gene accession numbers in the GenBank, localities and abbreviations in the tree of studied populations of $D$. lumholtzi.

\begin{tabular}{|c|c|c|c|c|}
\hline Abbreviation & Country & Locality & COI gene accession number & Reference \\
\hline Australia_1 & Australia & New South Wales & AF308970.1 & Hebert et al., 2002 \\
\hline Australia_2 & Australia & New South Wales & AY921417.1 & Colbourne et al., 2006 \\
\hline Thailand_1 & Thailand & Pond near Bung Pueng, Kalasin Province & & This study \\
\hline USA_MS1 & USA & Mississippi & AF308974.1 & Hebert et al., 2002 \\
\hline USA_KS1a-b & USA & Keith Sebelius Lake, Kansas & & This study \\
\hline USA_KS2a-d & USA & Wellington Lake, Kansas & & This study \\
\hline USA_NM1a-b & USA & Burn Lake, New Mexico & & This study \\
\hline USA_AZ1a-b & USA & Theodore Roosevelt Lake, Arizona & & This study \\
\hline Mexico_1a-e & Mexico & El Novillo, State of Sonora & $\begin{array}{c}\text { EU702127.1, EU702131.1, EU702128.1, } \\
\text { EU702129.1, EU702130.1 }\end{array}$ & Elías-Gutiérrez et al., 2008 \\
\hline Argentina_1a-c & Argentina & $\begin{array}{c}\text { Pond between Paraná and Santa Fe, } \\
\text { Santa Fe Province }\end{array}$ & & This study \\
\hline
\end{tabular}



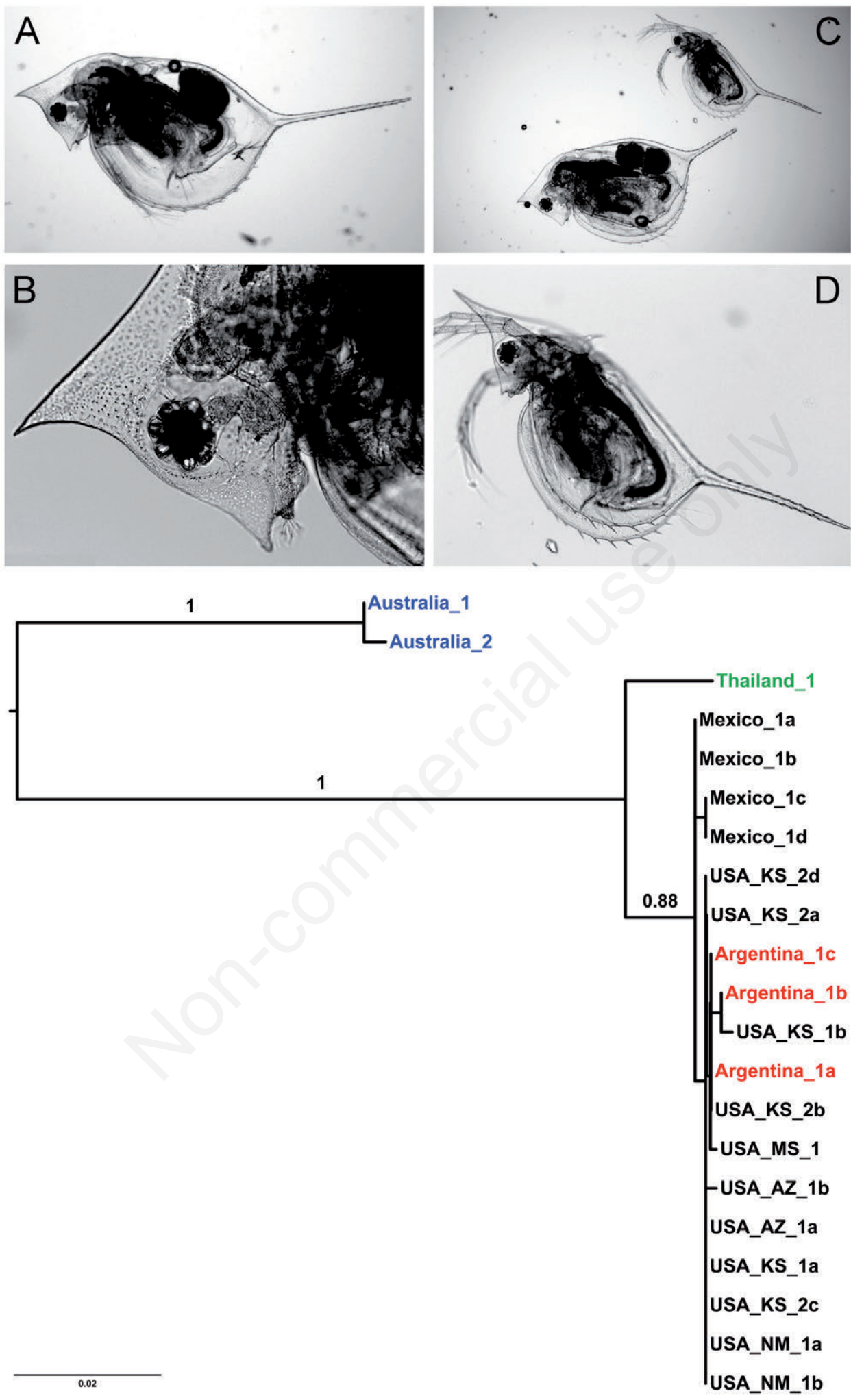

Fig. 2. Daphnia lumholtzi in Argentina. A-D) Different adult and juvenile females from a pool adjacent to the Paraná River, between Paraná and Santa Fe, Argentina. E) A Maximum Likelihood phylogram showing the close mitochondrial DNA sequence relationships of Argentinian D. lumholtzi to North American specimens. Support values given are nodes are approximate likelihood ratio tests (aLRTs). Blue, Australian specimens; green, Asian specimens; black, North American specimens; red, South American specimens. See Tab. 1 for further details on specimens. 
$37-38^{\circ} \mathrm{S}$ in Australia (S coast of New South Wales, see Benzie, 2005) and from the Republic of South Africa at about $30^{\circ} \mathrm{S}$ (Smirnov, 2008). Also, warm climate fails to predict the absence of this taxon in such countries as Spain, Italy, southern France etc., which are located significantly south from the northernmost border of the $D$. lumholtzi distribution. We failed to detect $D$. lumholtzi beyond the Paraná River system in Argentina or in Chile. As others have noted, temperature, dispersal limitation and other historical and biotic factors can interact in range expansion following invasion.

\section{CONCLUSIONS}

Given the rapid expansion and multiple modes of dispersal in North America and now South America, it is possible that there will be further expansion. Perhaps the species will reach about $30^{\circ} \mathrm{S}$ as it does in the Old World. The South American freshwater ecosystems and fisheries should be monitored closely to assess the possible ecological impact related to this successful invasive cladoceran.

\section{ACKNOWLEDGMENTS}

The study is supported by Biodiversity Program of the Presidium of Russian Academy of Sciences to AAK and an National Science Foundation Grant DEB0331095 to DJT. We thank M. Anderson, M. Balling, K. Costanzo, L. Hovind and W. Piel and for aid in collection.

\section{REFERENCES}

Adamowicz SJ, Hebert PDN, Marinone MC, 2004. Species diversity and endemism in the Daphnia of Argentina: a genetic investigation. Zool. J. Linnean Soc. 140:171-205.

Behning AL, 1928. [Studien ueber Crustaceen des Wolgabassins. 2. Daphnia lumholtzi G. O. Sars aus dem Wolgadelta].[Article in German]. Arch. Hydrobiol. 19:423-432.

Benson A, Maynard E, Raikow D, Larson J, Fusaro A, 2014. Daphnia lumholtzi. USGS Nonindigenous Aquatic Species Database, Gainesville, FL. Revision date: 30 May 2012. Available from: http://nas.er.usgs.gov/queries/FactSheet. aspx?speciesID $=164$

Benzie JAH, 2005. The genus Daphnia (including Daphniopsis) (Anomopoda: Daphniidae). Guides to the identification of the microinvertebrates of the continental waters of the world. Kenobi, Ghent and Backhuys Publ.: 376 pp.

Benzie JAH, Hodges AMA, 1996. Daphnia obtusa Kurz, 1874 emend Scourfield, 1942 from Australia. Hydrobiologia 333:195-199.

Burns CW, 2013. Predictors of invasion success by Daphnia species: influence of food, temperature and species identity. Biol. Invas. 15:859-869.

Colbourne JK, Wilson CC, Hebert PDN, 2006. The systematics of Australian Daphnia and Daphniopsis (Crustacea: Cladocera): a shared phylogenetic history transformed by habitatspecific rates of evolution. Biol. J. Linn. Soc. 89:469-488.

Crease TJ, Omilian AR, Costanzo KS, Taylor DJ, 2012.
Transcontinental phylogeography of the Daphnia pulex species complex. PLoS One 7:e46620.

Darriba D, Taboada GL, Doallo R, Posada D, 2012. jModelTest 2: more models, new heuristics and parallel computing. Nat. Methods 9: 772.

Dumont HJ, 1980. Zooplankton and science of biogeography: the example of Africa, p. 683-696. In: W.C. Kerfoot (ed.), Evolution and ecology of zooplankton communities. University Press of New England.

Dzialowski AR, O'Brien WJ, Swaffar SM, 2000. Range expansion and potential dispersal mechanisms of the exotic cladoceran Daphnia lumholtzi. J. Plankt. Res. 22:2205-2223.

Elías-Gutiérrez M, Martínez Jerónimo F, Ivanova NV, Valdez Moreno M, Hebert PDN, 2008. DNA barcodes for Cladocera and Copepoda from Mexico and Guatemala, highlights and new discoveries. Zootaxa 1839:1-42.

Fernando CH, Paggi JC, Rajapaksa R, 1987. Daphnia in tropical lowlands. Mem. Ist. Ital. Idrobiol. 45:107-141.

Folmer O, Black M, Hoeh W, Lutz R, Vrijenhoek R, 1994. DNA primers for amplification of mitochondrial cytochrome $\mathrm{c}$ oxidase subunit I from diverse metazoan invertebrates. Mol. Mar. Biol. Biotech. 3:294-299.

Forró L, Korovchinsky NM, Kotov AA, Petrusek A, 2008. Global diversity of cladocerans (Cladocera; Crustacea) in freshwater. Hydrobiologia 595:177-184.

Frisch D, Havel J, Weider LJ, 2013. The invasion history of the exotic freshwater zooplankter Daphnia lumholtzi (Cladocera, Crustacea) in North America - a genetic analysis. Biol. Invas. 15:817-828.

Glagolev SM, 1995. [Genus Daphnia, p. 48-58]. In V.R. Alekseev (ed.), [A key-book of the freshwater invertebrates of Russia and it vicinity. Vol. 2. Crustacea.].[Book in Russian]. ZIN Press.

Haney RA, Taylor DJ, 2003. Testing paleolimnological predictions with molecular data: the origins of Holarctic Eubosmina. J. Evol. Biol. 16:871-882.

Hasegawa M, Kishino H, Yano T, 1985. Dating of human-ape splitting by a molecular clock of mitochondrial DNA. J. Mol. Evol. 22:160-174.

Havel JE, Hebert PDN, 1993. Daphnia lumholtzi in North America: another exotic zooplankter. Limnol. Oceanogr. 38:18231827.

Havel JE, Colbourne JK, Hebert PDN, 2000. Reconstructing the history of intercontinental dispersal in Daphnia lumholtzi by use of genetic markers. Limnol. Oceanogr. 45:1414-1419.

Havens KE, East TL, Marcus J, Essex P, Bolan B, Raymond S, Beaver JR, 2000. Dynamics of the exotic Daphnia lumholtzii and native zooplankton in a subtropical chain-oflakes in Florida, USA. Freshwater Biol. 45:21-32.

Hayes KR, Barry SC, 2008. Are there any consistent predictors of invasion success? Biol. Invas. 10:483-506.

Hebert PDN, Remigio EA, Colbourne JK, Taylor DJ, Wilson CC, 2002. Accelerated molecular evolution in halophilic crustaceans. Evolution 56:909-926.

Heger T, Trepl L, 2003. Predicting biological invasions. Biol. Invas. 5:313-321.

Herbst HV, 1967. [Copepoda und Cladocera (Crustacea) aus Südamerika].[Article in German]. Gewäss. Abwäss. 44/45:96-108.

Kořínek V, 2002. Cladocera, p. 69-122. In: C.H. Fernando (ed.), 
A guide to tropical freshwater zooplankton. Backhuys Publ.

Lieder U, 1991. Bosmina kessleri-like morphotypes in Lake Muskoka, Ontario, Canada, as putative interspecific F1- hybrids. Hydrobiologia 225:71-80.

Mergeay J, Verschuren D, De Meester L, 2005. Cryptic invasion and dispersal of an American Daphnia in East Africa. Limnol. Oceanogr. 50:1278-1283.

Moyle PB, 1986. Fish introductions into North America: patterns and ecological impact, p. 27-43. In: H.A. Mooney and J.A. Drake (eds.), Ecology of biological invasions of North America and Hawaii. Springer.

Moyle PB, Marchetti MP, 2006. Predicting exotic fishes in freshwater systems: freshwater fishes in California as a model. BioScience 56:515-524.

Paggi JC, 1977. [Aportes al conocimiento de la fauna argentina de cladóceros. I. Sobre Daphnia laevis Birge 1878].[Article in Spanish]. Neotropica 23:33-37.

Paggi JC, 1993. [Análisis preliminar de la distribución geográfica de los cladóceros suramericanos]. [Article in Spanish]. In: A. Boltovskoy and H.L. López (eds.), Conferencias de Limnología. Instituto de Limnología "Dr. R. A. Ringuelet", La Plata, Argentina.

Popova EY, Kotov AA, 2013. Latitudal patterns in the diversity of two subgenera of the genus Daphnia O.F. Müller (Crus- tacea: Cladocera: Daphniidae). Zootaxa 3736:159-174.

Silva-Briano M, Arroyo-Bustos G, Beltran-Alvarez R, Adabache-Ortiz A, Galvan de la Rosa R, 2010. Daphnia Ctenodaphnia lumholtzi G.O. Sars, 1885 (Crustacea: Cladocera); an exotic cladoceran in Mexico. Hidrobiologica 20:275-280.

Simões NR, Robertson BA, Lansac-Tôha FA, Takahashi EM, Bonecker CC, Velho LFM, Joko CY, 2009. Exotic species of zooplankton in the Upper Paraná River floodplain, Daphnia lumholtzi Sars, 1885 (Crustacea: Branchiopoda). Braz. J. Biol. 69:551-558.

Smirnov NN, 2008. Check-list of the South-African Cladocera (Crustacea: Branchiopoda). Zootaxa 1788:47-56.

Sorensen KH, Sterner RW, 1992. Extreme cyclomorphosis in Daphnia lumholtzi. Freshwater Biol. 28:257-262.

Swaffar SM, O’Brien WJ, 1996. Spines of Daphnia lumholtzi create feeding difficulties for juvenile bluegill sunfish (Lepomis macrochirus). J. Plankton Res. 18:1055-1061.

Wittmann MJ, Gabriel W, Harz EM, Laforsch C, Jeschke JM, 2013. Can Daphnia lumholtzi invade European lakes? NeoBiota 16:39-57.

Zanata LH, Espindola ELG, Rocha O, Pereira RHG, 2003. First record of Daphnia lumholtzi (Sars, 1885), exotic cladoceran, in São Paulo State (Brazil). Braz. J. Biol. 63:717-720. 